\section{Cancer and Arylsulphatase Activity}

THREe arylsulphatases (arylsulphate sulphohydrolases E.C.3.1.6.1.) are known. Their distribution in the animal kingdom is very wide and their activity is low in such tissues as muscle and skin ${ }^{1,2}$ and high in liver and kidney ${ }^{2,3}$. There are some indications that arylsulphatase activity is modified in tumours ${ }^{2,4,5}$.

We have investigated the activity of arylsulphatase in cancers of the skin, stomach, colon and mammary gland.

$250 \mathrm{mg}$ of cancerous tissue extracted at operation were homogenized in $25 \mathrm{ml}$. of 0.5 molar acetate buffer, $p \mathrm{H} 5 \cdot 8$, for $3 \mathrm{~min} .0 .4 \mathrm{ml}$. of the homogenate was incubated for $24 \mathrm{~h}$ at $37^{\circ} \mathrm{C}$ with $0.4 \mathrm{ml}$. of 0.016 molar dipotassium 2 -hydroxy. 5 -nitrophenyl sulphate as substrate. The reaction was stopped by adding $3 \mathrm{ml}$. of 2 per cent phosphotungstate and the liberated 4-nitrocatechol was estimated colorimetrically after adding $5 \mathrm{ml}$. of a 10 per cent solution of sodium hydroxide containing 0.2 per cent quinol and 5 per cent sodium sulphite. The activity of arylsulphatase was expressed in umoles of 4-nitrocatechol per $0.4 \mathrm{ml}$. of 1 per cent homogenate (4 mg of wet tissue). Identical estimations on normal tissue of the organ from which the cancer originated were used as controls.

The cancerous character of the tissues was confirmed by histopathological examination. Wo have examined a total of nine cases of cancer of the stomach, nine cases of cancer of the colon, seven cases of cancer of the breast, four cases of malignant melanoma and one case of cancer of the skin.

Table 1 shows that in all cases of cancer examined the activity of arylsulphatase was elevated compared with the activity of the control tissue. The most marked increase occurred with malignant melanoma, which had a mean arylsulphatase activity more than eighty times higher than that of normal skin. The activity of arylsulphatase in one case of spino-cellular carcinoma of the skin was only ten times higher than the activity in normal skin.

Table 1. Aryldulphatase Activity of Some Cancerous Tissles eXPRESSED IN $\mu$ MOLES OF 4-NITROCATECHOL/4 MG OF WET TISSUE

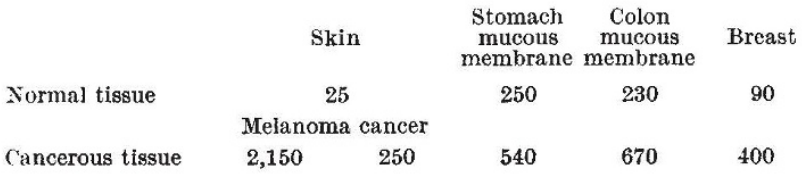

Arylsulphatase in tissue from cancer of the stomach was about twice as active as in normal gastric mucous membrane and five times as active as in the normal muscle layer. The activity of arylsulphatase in cancer of the colon was three times as high as the activity in normal mucous membrane of the colon and about fourteen times as high as that of the muscle layer. Cancer of the breast had an arylsulphatase activity which was about four times higher than the activity of normal mammary tissue.

\section{M. Dziaroszyński}

A. Fröhlich

J. KROLL

Department of Animal Physiology,

College of Agriculture,

Poznań, Poland, and

III Clinic of Surgery,

Medical Academy,

Poznań, Poland.

I Działoszyński, L. M., Nowak, J., and Fröhlioh, A. (unpublished results). 2 Huggins, C., and Smith, D. R., J. Biol. Chem., 170, 391 (1947).

3 Dodgson, K. S., Spencer, B., and Thomas, J., Biochem. J., 56, 177 (1956).

'Boyland, E., Wallace, D. M., and Williams, D. C., Brit. J. Cancer, 9, 6: $(1955)$.

${ }^{6}$ Działoszyński, L. M., and Zawielak, J., Acta Biochem. Polon., 2, 429 (1955).

\section{PHARMACOLOGY}

\section{Preparation and Identification of cis and} trans Isomers of a Substituted Triarylethylene

We have prepared a series of 1 - $(p$-dialkylamino alkoxy phenyl) 2 alkyl-1,2-diphenylethylenes ${ }^{1}$ and in many instances have isolated the respective isomers ${ }^{2}$. The differences in biological activity of one pair of cis and trans isomers, I.C.I. compounds Nos. 47,699 and 47,644 . respectively, have already been described ${ }^{3}$.

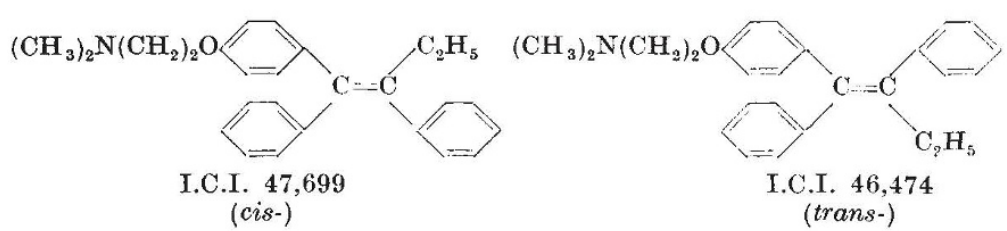

A mixture of these isomers was obtained by dehydration of 1 - (4- $\beta$-dimethylaminoethoxyphenyl) - 1,2 - diphenylbutanol by heating the latter under reflux with ethanolic hydrochloric acid and converting the resulting mixed hydrochloride to base. The crude mixture was slurried with petroleum ether (boiling point $40^{\circ}-60^{\circ} \mathrm{C}$ ) and the insoluble material crystallized from the petroleum ether (b.p. $60^{\circ}-80^{\circ} \mathrm{C}$ ). In this way the trans isomer (melting point $96^{\circ}-98^{\circ} \mathrm{C}$ ) was obtained. The cis isomer (m.p. $72^{\circ}$ $74^{\circ} \mathrm{C}$, after crystallization from methanol) separated from the petroleum ether liquors (b.p. $40^{\circ}-60^{\circ} \mathrm{C}$ ). The preferred method of preparation of the intermediate butanol is by the reaction of phenylmagnesium bromide or phenyl lithium with 4 - $\beta$-dimethylaminoethoxy- $\alpha$-ethyldesoxybenzoin.

Table 1. Chemicai Shifts $(\tau)$ of the Two Isomers

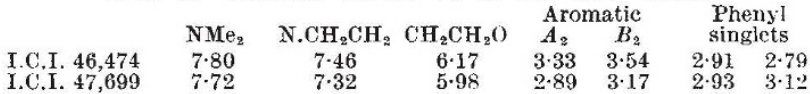

Table 2. Chemical Shipt Data $(\tau)$ and Dipoly Moments (Deryf)

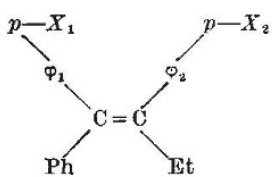<smiles>[Y9]OC([Z17])C(OC)c1ccccc1</smiles>

$\begin{array}{llll}X_{1} & X_{2} & \mathrm{Ph} & \\ & & & \mathrm{H}_{4} \\ \mathrm{Me}_{2} \mathrm{~N}\left(\mathrm{CH}_{3}\right)_{2} \mathrm{O} & \mathrm{H} & 2 \cdot 79 & 3.33 \\ \mathrm{MeO} & \mathrm{H} & 2 \cdot 78 & 3.3 \\ \mathrm{MeO} & \mathrm{MeO} & 2 \cdot 79 & 3.29 \\ \mathrm{Cl} & \mathrm{Cl} & 2 \cdot 79 & 3.02\end{array}$

\begin{tabular}{|c|c|c|}
\hline $\mathbf{H}_{\boldsymbol{A}}$ & $\mathrm{H}_{B}$ & $\mathrm{H}_{A}$ \\
\hline $\begin{array}{l}3 \cdot 33 \\
3 \cdot 30\end{array}$ & $\begin{array}{l}3.54 \\
3.55 \\
3.51 \\
3.94\end{array}$ & $\begin{array}{l}2 \cdot 91 \\
2 \cdot 92 \\
3.01 \\
9.00\end{array}$ \\
\hline
\end{tabular}

$\varphi_{2} \begin{aligned} & \\ & \mathrm{H}_{B} \\ & 2 \cdot 91 \\ & 2 \cdot 92 \\ & 3.37 \\ & 2 \cdot 98\end{aligned}$
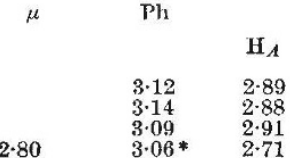

$\varphi_{1}$
$\mathrm{H}_{\boldsymbol{B}}$
$3 \cdot 17$
$3 \cdot 21$
$3 \cdot 21$
$2 \cdot 88$

$\mathbf{H}_{B}$
2.93
2.94
3.00
2.94

$\mathrm{H}_{B}$
2.93
2.94
3.40
2.98

le

$\mathrm{H}_{A}$, Aromatic protons adjacent to the ethylenic double bond. $\mathrm{H}_{B}$, Aromatic proton adjacent to the substituent. * Multiplet. 